\title{
Symbolic Meanings in Marriage Ceremony of Javanese Culture (Semiotic Analysis)
}

\author{
Jumino \\ \{jumino@live.undip.ac.id\} \\ Department of English Literature, Faculty of Humanities, Diponegoro University \\ Semarang, 50275, Indonesia
}

\begin{abstract}
Javanese wedding ceremony consists of various symbolic processions during the ceremony. The ceremony starts from wedding prerparation, pemasangan decorasi (decorating), siraman (watering body), potong rikmo (haircut), selling dawet, midodareni (visiting to the bride), ijab kabul (marriege pledge), panggih (meeting), balang suruh (throwing suruh), wiji dadi (hoping fertile), dahar kembul (having meal together), sungkeman (prostating), sindur mayang (covering shawl), timbang (weighing), tukar cincin (exchanging ring), until wedding reception. Each procession has both its own symbol and meaning.
\end{abstract}

Keywords: Marriage; wedding; tradition, procession; bride; bridegroom; Javanese culture.

\section{Introduction}

Indonesia has a variety of cultures. According to Thohir, the form of culture is in the form of a complex of ideas, values, norms, or abstract rules [1].

One form of culture is Javanese traditional marriage. Mantle Hood, in Sutawijaya, [2] states that the Javanese culture is from here to eternity. In the context of Javanese customary marriage, it is focused on marriage data in Central Java in the city of Solo and Yogyakarta.

The traditional tradition of marriage has distinctive characteristics in each region. However, all of them contain very high cultural values from each procession in marriage. Each procession is carried out with meaningful sacred symbols. According to Geerts, the power of symbols is the ability to identify facts with values at the most fundamental level [3].

In the Javanese traditional marriage procession, various stages must be passed, before the bride and bridegroom have the right to bear the title as husband and wife.

\section{Theoretical Framework}

Semiotic or semiology is the terminology that refers to the same science. In Greek, semiotic (semeion $=$ sign $)$ is a branch of science that deals with signs and everything relating to signs, such as sign and process systems that apply to the use of the mark [4]. The term derived from the Greek word semeion meaning "sign" in English is a science that studies the system of sign such as: language, code, signal, and so forth.

Initially the semiotic concept was introduced by Ferdinand de Saussure through dichotomous system of signification, signified, and signified. This concept sees that the meaning arises when there is an associative relationship or in absentia between the "signified" and the "signifier". The sign is the unity of a signifier with an idea or signified. In other words, markers are meaningful sounds. So, the marker is a material aspect of the language that 
is what is said or heard and what is written or read. Thus, a sign is a mental aspect of the language [5].

Semiotic basically wants to learn how human means things. Understanding (signifying) in this case cannot be confused with communicating. Meaning means that objects do not only carry information, in the case where the objects are to be communicated, but also constitute a structured system of signs. The connotation, even though it is the original nature of the sign, requires the activeness of the reader to function. In Barthes's semiology and its followers, denotation is the first level of significance system, while the connotation is the second level. He further states that the literal meaning is something of a nature [6].

In the framework of Barthes [6], connotations are identical to ideological operations, which he calls "myth" and function to reveal and justify the dominant values that apply within a certain period. In "myth" there is also a three-dimensional pattern of signifier, signified, and sign.

To be able to identify a "sign", it must first be understood exactly what is meant by a "sign". In semiotics, symbols can be words, or images that can produce meaning. Each sign consists of a "signifier" (marker) in the form of the signature - and 'signified' the concept represented by the marker [7].

According to Peirce, as quoted by Fiske [8], there are three signs, namely: (1) "Iconic": a similar sign to the tagged (for example: photos, brand photos, diagrams, maps); (2) "Symbolic": a sign that is not identical to those marked but conventional arbiters and mummies (e.g: the word stop / red traffic light; (3) "Indexical": a sign that is associated automatically in a case (existential or causal) with a marked (e.g: smoke indicating fire). These three types of sign do not need to be separated from one another: something can be an icon, symbol and index, or a combination of all three. Movies and television, for example, use the three categories: icons (sounds and pictures), symbols (speechs and texts), and indexes (as a result of filmmaking).

\section{Method}

This study uses library research methods. Methods of research in this study include: 1) close reading, 2) textual analysis, and 3) inter-textual and contextual analysis using semiotic method.Careful reading is done on material objects in the form of writings on ceremonial services of Java as the source of primary data. Then the source of the primary data is analyzed in textual, inter-textual, and contextual according to the theoretical basis used.

\section{Results and Discussion}

There are several stages and ceremonies that must be passed in a wedding procession in Javanese custom. The stages and ceremonies are: 1). Persiapan Pesta Perkawinan (Wedding marriage preparation), 2). Pemasangan Dekorasi (Decoration installation), 3). Siraman (watering body), 4). Potong Rikmo (Haircut), 5). Dodol Dawet (Selling dawet), 6). Midodareni (Visiting to the bride), 7). Ijab Kabul (Marriage pledge), 8). Panggih (Meeting), 9). Balang Suruh (Throwing Suruh)), 10). Wiji Dadi (Making fertile), 11). Dahar Kembul (Having meal together), 12). Sungkeman (Prostating), 13). Sindur Binayang (Putting shawl), 14). Timbang (Weighing), 15). Tukar Kalpika (Putting on a ring each other), and 16).. Ularular (Giving advice). 


\subsection{Wedding Marriage Preparation}

In Javanese customs, who have the intention or job is the bride's future bride. The size of the party depends on the status and capabilities of the parents, and also the amount of petukon received by the parents. Given the significance of the marriage, the day of execution of the ijab was done elaboratively so that the couple would have lasting happiness, avoided from trials and dangers.

\subsection{Pemasangan Dekorasi (Decoration installation)}

When the wedding reception takes place at home, usually a day before the party, the gate from the parent's house of bride is decorated with tarub (the decoration of plants). Equipment or ubo rampe consists of banana trees, banana fruit, sugar cane, coconut fruit and coconut leaves which each have their own meaning. Two banana trunks with some banana combs mean that the husband should be role models in family and social life

\subsection{Siraman (Watering body)}

Siraman is a procession for cleansing the soul and body, as well as removing all the invisible brides. It is hoped that the bride and bridegroom can start a new life with a clean and pure heart.

\subsection{Potong Rikmo (haircut)}

After the watering body procession is completed, then potong rikmo or haircut from both bride and bridgroom. The two haircuts are then put together to be planted. This refers to self cleansing and equal perception before they step into marriage.

\subsection{Dodol Dawet (Selling dawet)}

After the haircut process is finished, then dodol dawet is done. Dodol dawet which means selling traditional Javanese drink dawet. Dawet is a typical Javanese traditional drink made of cendol (jelly). The father who brings, while the mother who serves the buyers. This gives an example of a good synergy between husband and wife in order to make a living.

\subsection{Midodareni (Visiting to the Bride))}

Midodareni event is held on the night of the day before the wedding day of the marriage ceremony. The bridegroom accompanied by his relatives and friends visits the house of his prospective father-in-law and and handed to be married on the following day. The bride who is regarded as an angel needs the safety of her. For that, the bridegroom will invite relatives and close friends for a couple of hours on the eve of the wedding at the bride's wedding.

\subsection{Ijab Kabul (Marriage pledge)}

Ijab kabul ceremony is the most important requirement in confirming marriage. Implementation of ijab kabul is done in accordance with the religion of the bride and 
bridegroom. At the time of ijab kabul, the father of the bride marries his daughter with the bridegroom. Furthermore, the bridegroom receives his marriage from the parents of the bride and the bridegroom then accompanied by a dowry handover for the bride. This event is interpreted as fulfillment of the wishes of both to form a family.

\subsection{Panggih (Meeting)}

The panggih ceremony is a meeting between a beautiful bride and a handsome young bride in front of the house decorated with tarub plants. Bridegroom was escorted by his family to the bride's bride's house and stopped at the gate. The bride and bridegroom, accompanied and escorted by two women who were married, walked out of the bridal room. His parents and close family walked behind him. However, now this procession is usually held at a building where the wedding party is held.

\subsection{Balang Suruh (Throwing suruh)}

The bride meets with the bridegroom. They approach each other. With the distance of about three meters, they throw a bunch of leaves with an orange inside tied with white thread. They are doing with great desire and hope for happiness later on. According to tradition, the leaves have the power to resist from bad disturbances. By throwing suruh leaves each other, they will prove to themselves that they are truly true humans, not demons or others who consider themselves to be the bride or the bridegroom.

\subsection{Wiji Dadi (Making fertile)}

In this ceremony, the bridegroom steps on the egg with his right foot. Then the bride washes the bridegroom's feet with water mixed with various flowers. It is meant that the bridegroom is ready to be a responsible father and husband, while the bride will be faithful to her husband.

\subsection{Dahar Kembul (Having meal together)}

The bride and bridegroom have meal together and fed each other. First, the bridegroom makes three small circles of rice with his right hand and gives it to the bride. After the bride eats, she does the same for her husband. After they finish, they drink sweet tea. The ceremony illustrates that the bride and bridegroom will use and enjoy a happy life with no interference from others.

\subsection{Sungkeman (Prostating)}

In this ceremony, the bride and bridegroom prostrate to both parents to pray for their blessing from parents. First it is done with the bride's parents, then with the bridegroom's parents. During sungkeman in progress, Pemaes takes a keris from the bridegroom. After Sungkeman, the bridegroom wore his keris back. This is meant as a sign of the bride and bridegroom to their parents without any suspicion.

\subsection{BinayangSindur (Putting shawl)}


After the wiji dadi procession, the bride and bridegroom's parents are in front of the bridegroom's chair, while the bride's mother puts the shawl (sindur) over the shoulders of the bride as a symbol in which a father's figure shows the way of life they are going through their mother tut wuri handayani, walking back while giving advice.

\subsection{Timbang (Weighing)}

In this procession, the bride and bridegroom sit in the lap of the bride's bride. The father then said that the scales were "equally heavy". It is meant that both will be equally loved and loved. Both are treated equally as their own and have the same position in front of the parents.

\subsection{Tukar Kalpika (Putting on a ring each other)}

In this procession, the bride and bridegroom give a ring to each other as a sign of dependence to each other. As a sign of loyalty, the ring will always stick to their finger. For those who have done tukar kalpika before, this procession only transfers the ring from the left hand finger to the right hand one alternately.

\subsection{Ular-ular (Giving Advice)}

Giving advice is part of the celebration in a marriage ceremony that is usually conveyed by a person who has broad knowledge and charismatic in the family environment. The purpose of giving advice is to give the bride and bridegroom to safeguard the life journey until old age.

\section{Conclusion}

Each stage of the procession of marriage in Javanese customs contains semiotic values, full of meaning and expectations of the desired life. With symbols in wedding procession, a man and a woman united by bonds of marriage are expected to live together as a husband and a wife forever. Marriage is an important event in a life, once in a life.

\section{Acknowledgements}

The writer thanks to say thanks to (1) Dr. Deli Nirmala, M.Hum., (2) Dr. Agus Subiyanto, M.A., and (3) Rifka Pratama, S.Hum., M.A. for their help and support.

\section{References}

[1] Thohir, Mudjahirin. Memahami Kebudayaan. Semarang: Fasindo Press (2007).

[2] Sutawijaya, Danang. Upacara Penganten, Semarang, Aneka Ilmu (2001).

[3] Geertz, Clippord. Kebudayaan dan Agama, Yogyakarta, Penerbit Kanisius (1992).

[4] Zoest, Aart van. Interpretasi dan Semiotik, Serba-serbi Semiotik, Jakarta, Gramedia. (1992).

[5] Bertens, H. The Basic Literary Theory. London \& New York: Routledge (2001).

[6] Barthes, Roland. Membedah Mitos-mitos Budaya Massa (Translated by Ikramullah Mahyuddin), Penerbit Jalasutra, Yogyakarta (2007).

[7] Wardoyo, Subur. Semiotika dan Struktur Narasi. Kajian Sastra Vol. 29, No. 1 (2005).

[8] Fiske, John. Introduction to Comminication Studies. London: Routledge (1990). 